\author{
AnNA STRZEPA, BARBARA MACURA, MARIAN SzCZEPANIK \\ Katedra Biologii Medycznej \\ Collegium Medicum Uniwersytet Jagielloński \\ Kopernika 7, 31-034 Kraków \\ E-mail: mmszczep@cyf-kr.edu.pl \\ marian.szczepanik@uj.edu.pl
}

\title{
ZABURZENIA SNU W STWARDNIENIU ROZSIANYM
}

\section{WSTEP}

Okołodobowe zmiany rytmu snu i czuwania zależne sa od współdziałania kilku neurotransmiterów. Nieprawidłowe działanie neurotransmiterów obserwuje się m.in. u osób cierpiących na schorzenia psychiatryczne i neurodegeneracyjne. U przeważajacej większości osób cierpiących na schorzenia afektywne oraz u znacznej części pacjentów ze schorzeniami neurodegeneracyjnymi, takimi jak stwardnienie rozsiane (łac. sclerosis multiplex, SM), choroba Parkinsona czy choroba Alzheimera, obserwuje się również współistnienie zaburzenia snu. Nieprawidłowości związane ze snem prowadza do pogorszenia funkcji poznawczych, zmian emocjonalnych, zaburzeń metabolicznych i osłabienia odporności. Wydaje się zatem, że schorzenia neurologiczne oraz nieprawidłowości w fazach snu i jego długości sa ze soba powiazane, a normalizacja jednego $z$ tych stanów będzie prowadzić do poprawy drugiego. Dodatkowo, obserwacja zmian w przebiegu snu może często służyć do monitorowania efektywności zastosowanej terapii w schorzeniach neurologicznych (BRAss i współaut. 2010).

\section{ETIOLOGIA SM}

Stwardnienie rozsiane to schorzenie, w którym przewlekły stan zapalny w ośrodkowym układzie nerwowym (OUN), zwiazany $z$ rozszczelnieniem bariery krew-mózg (ang. blood-brain barier, BBB) oraz migracja leukocytów do OUN, prowadzi do demielinizacji, a po pewnym czasie do śmierci neuronów.
Zmiany te prowadza do postępującego osłabienia funkcji fizycznych, poznawczych, emocjonalnych i społecznych chorego. Stwardnienie rozsiane dotyka 2,3 miliona osób na świecie, głównie kobiet, i jest jednym $z$ najczęstszych schorzeń o podłożu neurologicznym u ludzi młodych (MATVEeva i współaut. 2018). SM pojawia się zwykle około 30 roku życia i trwa przez około 45 lat, prowadzacc do nieznacznego skrócenia czasu życia chorych (RANSOHOFF 2016).

Sposób progresji choroby jest zróżnicowany. U 85\% chorych pojawiaja się krótkotrwałe lub trwajace dniami lub tygodniami ataki (rzuty, nawroty), w czasie których obserwowane jest pogorszenie funkcji neurologicznych. Pomiędzy rzutami obserwuje się okresy (remisje), w czasie których następuje całkowita lub częściowa poprawa funkcjonowania organizmu. Postać ta określana jest jako rzutowo-remisyjna (ang. relapsing-remitting multiple sclerosis, RRMS) i u większości pacjentów przechodzi w postać wtórnie-postępująca, w której obserwuje się brak rzutów i postępujące pogorszenie funkcji neurologicznych. U częśsi pacjentów nie obserwuje się początkowego etapu rzutów i remisji, a pogarszanie się funkcji neurologicznych następuje w sposób ciagły. Postać ta opisywana jest jako pierwotnie-postępująca (RANSOHOFF 2016).

Mechanizmy prowadzace do rozwoju stwardnienia rozsianego nie sa do końca poznane. Wydaje się, że na rozwój choroby wpływaja czynniki środowiskowe, które u podatnych genetycznie osób promują przelamanie stanu tolerancji układu immunologicznego na antygeny własne, znajdujące 
się w OUN, i w konsekwencji dochodzi do aktywacji autoreaktywnych limfocytów T i B (TUTAJ i SZCZEPANIK 2006).

Zachorowalność na SM związana jest $z$ szerokością geograficzna. Najwięcej przypadków obserwuje się $\mathrm{w}$ wysoko zindustrializowanych krajach Ameryki Północnej i Europy, natomiast znacznie rzadziej w krajach Ameryki Południowej i Afryki. Przemieszczenie się osób młodych przed 15 . rokiem życia między tymi strefami prowadzi do zmiany ryzyka zachorowalności migranta do poziomu obserwowanego $\mathrm{w}$ danej populacji (TUTAJ i SZCZEPANIK 2006). Tendencja ta i ograniczona geograficznie zachorowalność, łączone sa $z$ : sezonowymi zmianami w nasłonecznieniu, wpływajacymi na poziom witaminy $\mathrm{D}$, obecnościa w tych rejonach specyficznych czynników patogennych, a także $z$,zachodnim stylem życia". Witamina D odpowiada nie tylko za prawidłowe funkcjonowanie tkanki kostnej, ale także reguluje pracę układu immunologicznego, działajac przeciwzapalnie poprzez promowanie rozwoju limfocytów $\mathrm{T}$ regulatorowych (Treg) (SINTZEL i współaut. 2018). Chociaż głównym źródłem witaminy D jest ekspozycja na promieniowanie słoneczne zaobserwowano, że kobiety spożywajace więcej witaminy $\mathrm{D}$ maja niższe prawdopodobieństwo rozwoju SM i dodatkowo, do manifestacji schorzenia dochodzi w późniejszym okresie życia (MUNGER i współaut. 2004). Rozwój przemysłowy zmienił sposób odżywiania, wprowadzając do diety produkty wysoko przetworzone, bogate $\mathrm{w}$ sól, długolańcuchowe kwasy tłuszczowe, kwasy tłuszczowe trans, tłuszcze o podwyższonym poziomie kwasów $\omega-6$, które działaja prozapalnie poprzez promowanie rozwoju limfocytów pomocniczych Th1 i Th17. Równocześnie, dieta zachodnia uboga jest $\mathrm{w}$ antyoksydacyjne flawonoidy, przeciwzapalne kwasy $\omega-3$ i błonnik, z którego powstaja krótkołańcuchowe kwasy thuszczowe (ang. short chain fatty acids, SCFA), promujace rozwój limfocytów Treg (Matveeva i współaut. 2018). Dodatkowo, zmiana sposobu odżywiania prowadzi do zmiany kompozycji bakterii jelitowych (mikrobioty), co określane jest jako dysbioza jelitowa. Jak obecnie wiadomo, mikrobiota jelitowa modyfikuje, bezpośrednio albo pośrednio, za pomoca wytwarzanych metabolitów, systemowa odpowiedź immunologiczna. Co ciekawe zaobserwowano, że pacjenci cierpiący na SM maja zmieniony profil jelitowej mikrobioty (STRZEPA i współaut. 2018). Industrializacja zmieniła nie tylko sposób odżywiania, ale również sposób życia przez wszechobecne sztuczne oświetlenie, które umożliwiło pracę zmianowa. Praca zmianowa lączona jest $z$ negatywnymi konsekwencjami zdrowotnymi, do których można zaliczyć zwiększona częstość schorzeń autoimmunologicznych, w tym również SM (HEDSTRÖM i współaut. 2015). Chociaż przyczyny tej asocjacji nie sa $\mathrm{w}$ pełni zrozumiałe, podejrzewa się, że negatywny wpływ pracy zmianowej na rytm dobowy zwiazany jest $z$ cyklem snu i czuwania.

Obecność SM w rodzinach wskazuje na rolę podłoża genetycznego jako czynnika wpływającego na rozwój choroby. Badania asocjacyjne całego genomu (ang. genome-wide association studies, GWAS), wykazały obecność licznych loci zwiększających prawdopodobieństwo rozwoju tego schorzenia (PARKES i współaut. 2013). Za 20-30\% podatności na SM odpowiadaja rejony znajdujace się na chromosomie 6, kodujace antygeny zgodności tkankowej HLA (ang. human leukocyte antigens) (HAINEs i współaut. 1998). Wykazano, że posiadanie haplotypu HLA DRB1*1501, trzykrotnie zwiększa prawdopodobieństwo rozwoju SM, w porównaniu do osób posiadajacych inny haplotyp (THOMPSON i współaut. 2018). Polimorfizmy zwiększajace podatność na SM odpowiadaja za procesy zwiazane $z$ prezentacja antygenu, komunikacja za pomoca cytokin czy regulacja odpowiedzi zapalnej za pośrednictwem czynnika transkrypcyjnego NF-kB (PARKES i współaut. 2013) i znajduja się zarówno w sekwencjach kodujacych, jak i regulacyjnych, które podlegaja modyfikacjom epigenetycznym w limfocytach T i B (FARH i współaut. 2015). Pomimo widocznej asocjacji między podłożem genetycznym a rozwojem stwardnienia rozsianego, analiza częstości choroby u bliźniąt jednojajowych nie wykazuje tak jednoznacznej zależności. Niektóre badania wskazuja na współwystępowanie schorzenia (tzw. concordance rates) u 25-30\% bliźniąt jednojajowych i tylko u 5\% bliźniąt dwujajowych (WILler i współaut. 2003). Inne dane natomiast wskazuja na brak takiej zależności (RISTORI i współaut. 2006).

\section{ROLA UKŁADU IMMUNOLOGICZNEGO W SM}

Uszkodzenie OUN w stwardnieniu rozsianym powstaje na skutek interakcji pomiędzy układem immunologicznym, neuronami i komórkami gleju, a więc mikrogleju, oligodendrocytów i astrocytów. Analiza porównawcza ekspresji genów w obrębie zmian patologicznych w rejonach korowych wykazała, że schorzenie zwiazane jest $z$ ekspresja genów regulujacych odpowiedź zależna od limfocytów pomocniczych Th1/Th17, a także aktywacja mikrogleju, stresem oksydacyjnym, mechanizmami zwiazanymi $z$ uszkodzeniem i naprawa DNA, a także remielinizacją i procesami naprawczymi (FISCHER i współaut. 
2013). Dodatkowo, biorąc pod uwagę asocjację określonych haplotypów HLA z rozwojem SM oraz obecność limfocytów w rejonach demielinizacji przyjmuje się, że rozwój schorzenia zwiazany jest $Z$ aktywacja antygenowo-swoistych limfocytów T i B (LASSMANN 2014, THOMPSON i współaut. 2018). Analiza receptorów limfocytów $\mathrm{T}$ pochodzacych $\mathrm{z}$ płynu mózgowo-rdzeniowego pacjentów cierpiących na SM wskazuje, że dochodzi do ekspansji klonalnej, potwierdzając istotna rolę limfocytów T w patogenezie schorzenia (BABBE i współaut. 2000). Ponadto, aktywacja limfocytów B u pacjentów $z$ SM prowadzi do produkcji przeciwciał, które sa widoczne w postaci osobnych pasm w trakcie rozdziału elektroforetycznego białek płynu mózgowo-rdzeniowanego, ale nie w surowicy. Pasma te określane sa jako prażki oligoklonalne i stanowia potwierdzenie zaangażowania układu odpornościowego w patogenezie SM (TUTAJ i SzCZEPANIK 2006). Obecność prążków oligoklonalnych w płynie mózgowo-rdzeniowym pacjentów cierpiących na SM, ale nie w ich surowicy, a także obecność nacieków limfocytarnych w OUN sugeruje, że limfocyty rozpoznaja antygeny znajdujace się w OUN. Potwierdzaja to badania na modelach zwierzęcych, w których eksperymentalne autoimmunizacyjne zapalenie rdzenia kręowego i mózgu (ang. experimental autoimmune encephalomyelitis, EAE) indukować można przez podanie homogenatu rdzenia kręgowego lub przez podanie wraz $z$ adiuwantem antygenów znajdujacych się w tkance nerwowej, to jest zasadowego białka mieliny (MBP), glikoproteiny oligodendrocytów mieliny (MOG) lub proteolipidu (PLP) (TUTAJ i SzCZEPANIK 2006, HohlfEld i współaut. 2016). Podanie antygenu prowadzi do aktywacji antygenowo swoistych limfocytów $\mathrm{T} \mathrm{CD}^{+}$, które sa wystarczające, aby przenieść schorzenie do zdrowych biorców (TUTAJ i SzCZEPANIK 2006).

Obecność limfocytów T $\mathrm{CD}^{+}{ }^{+}$wykazano w zmianach patologicznych znajdujacych się w OUN i płynie mózgowo-rdzeniowym pacjentów (TRaugotT i współaut. 1983). Pełnia one rolę patologiczna, gdyż ekspansja limfocytów T swoistych dla MBP następujaca po próbie terapeutycznego podania zmodyfikowanego MBP, prowadziła do powstania nowych zmian ogniskowych, widocznych po podaniu kontrastu (MARTIN i współaut. 2000). W schorzeniu biora udzial limfocyty $\mathrm{T} \mathrm{CD}^{+}$ produkujace IFN- $\gamma$ (IFN- interferon) i IL-17A. Podanie IFN- $\gamma$ pacjentom cierpiacym na SM prowadziło do zaostrzenia schorzenia (PANITCH i współaut. 1987), natomiast zmniejszenie poziomu IL-17, przez aplikację przeciwciał monoklonalnych anty-IL-17, ograniczało rozwój zmian chorobowych (HAVRDOVÁ i współaut. 2016). Pomimo że w warunkach eksperymentalnych adaptywny transfer limfocytów Th1 i Th17 prowadzi do przeniesienia EAE na naiwnych biorców, rola wspomnianych cytokin $\mathrm{w}$ patogenezie EAE jest nadal niejasna (LUGER i współaut. 2008). Produkcja IFN- $\gamma$ przez limfocyty T zależy od IL-12, zbudowanej $z$ podjednostki p35 i p40. Podjednostka p40 jest również składnikiem IL-23, która wspomaga indukcję limfocytów Th17. Zgodnie $z$ przypuszczeniami, myszy nieposiadajace podjednostki IL-12/IL-23 p40 chronione sa przed rozwojem EAE. Nieoczekiwanie, myszy nieposiadajace podjednostki IL-12 p35, a tym samym nie produkujace IL-12, ale produkujace IL-23, nie sa chronione przed rozwojem EAE, co sugeruje, że rola IFN- $\gamma$ nie musi być patologiczna (BECHER i współaut. 2002). Niestety, badania kliniczne nad ustekinumabem, przeciwciałem monoklonalnym rozpoznajacym podjednostkę IL-12/IL-23 p40, nie wykazały skuteczności zastosowanego preparatu sugerując, że również rola IL-17 w patogenezie SM może być zróżnicowana (SEGAL i współaut. 2008). Przykładowo, wpływ produkowanej IL-17 może być uzależniony od populacji produkujacych ja komórek. Limfocyty Th17, produkujące również IFN- $\gamma$, wydają się być bardziej patogenne, niż komórki produkujące tylko IL-17. Zatem wielu badaczy wskazuje na rolę zarówno IFN- $\gamma$, jak i IL-17A w patogenezie SM.

Limfocyty $\mathrm{T} \mathrm{CD}^{+}$odgrywaja znacznie bardziej istotną rolę $\mathrm{w}$ ludzkim SM niż w EAE. Zaobserwowano, że limfocyty $\mathrm{T} \mathrm{CD}^{+}$ stanowią dominująca populację nacieków okołonaczyniowych (TRAUGOTT i współaut. 1983) oraz pięćdziesięciokrotnie przewyższają liczbę limfocytów $\mathrm{T} \mathrm{CD}^{+} \mathrm{w}$ rejonach, w których dochodzi do aktywnej demielinizacji (HAUSER i współaut. 1986). Liczba limfocytów T $\mathrm{CD}^{+}$wzrasta również w płynie mózgowo-rdzeniowym chorych na SM, w porównaniu $z$ osobami zdrowymi. Indukcja limfocytów $\mathrm{T}$ $\mathrm{CD}^{+}$następuje po rozpoznaniu antygenu w kontekście MHC I. Antygeny zewnętrzne, takie jak antygeny osłonek mielinowych, moga być zaprezentowane w kontekście MHC I dzięki krzyżowej zdolności do prezentacji, jaka posiadają komórki mikrogleju (ZANG i współaut. 2004). Patologiczna rola limfocytów $\mathrm{T} \mathrm{CD}^{+}$w SM zwiazana jest $z$ cytotoksycznym uszkadzaniem komórek produkujących mielinę, oraz produkcja IFN- $\gamma$ i IL-17A, wzmacniająca patogenność limfocytów Th17 (MElzer i współaut. 2009, HuBER i współaut. 2013).

Limfocyty regulatorowe wpływaja na czas i siłę odpowiedzi immunologicznej. Możemy do nich zaliczyć naturalne limfocyty regulatorowe $\mathrm{CD}^{+}{ }^{+}$FoxP3 ${ }^{+}$Treg i limfocyty regulatorowe $\mathrm{CD}^{+}{ }^{+} \mathrm{Tr} 1$. Pierwsza grupa limfocytów 
różnicuje się dzięki czynnikowi transkrypcyjnemu FoxP3, działa w sposób antygenowo-swoisty, a do pełnienia swoich funkcji wymaga bezpośredniego kontaktu $\mathrm{z}$ komórka docelowa. Myszy scruffy, które mają mutację $\mathrm{w}$ genie FoxP3, jak również myszy $\mathrm{z}$ nieaktywnym genem FoxP3, nie posiadaja wywodzących się $z$ grasicy naturalnych limfocytów Treg, co skutkuje rozwojem zespołu limfoproliferacyjnego (BRUNKOw i współaut. 2001) i wielonarzadowego stanu zapalnego, ale bez zapalenia tkanki nerwowej. Nie oznacza to jednak, że limfocyty Treg nie kontroluja stanu zapalnego w OUN, gdyż wykazano, że adoptywny transfer limfocytów $\mathrm{CD}^{+}$ FoxP3 ${ }^{+}$Tregs lagodził przebieg EAE (КоHM i współaut. 2002) lub całkowicie uniemożliwiał rozwój spontanicznego EAE u myszy transgenicznych, posiadajacych receptory antygenowe TCR rozpoznajace mielinę (HORI i współaut. 2002). Równocześnie, większość badań wskazuje na brak istotnych różnic w liczbie limfocytów Treg pomiędzy chorymi na SM a osobami zdrowymi, co sugeruje, że zmiana może mieć charakter jakościowy, a nie ilościowy (BAECHER-ALLAN i współaut. 2018). Stan zapalny w tkance nerwowej zwiazany jest $z$ obecnością IL-6. Wykazano, że IL-6 nie tylko promuje powstawanie limfocytów Th17 kosztem limfocytów Treg, ale również może ograniczać zdolności supresyjne limfocytów Treg (BHELA i współaut. 2015), a także promować rozwój niewrażliwości limfocytów $\mathrm{T}$ efektorowych na działanie limfocytów Treg (SCHNEIDER i współaut. 2013).

Przynależność do populacji limfocytów $\mathrm{CD}^{+} \operatorname{Tr} 1$ determinowana jest przede wszystkim przez zdolność do intensywnej produkcji interleukiny przeciwzapalnej IL-10. Brak jest czynników transkrypcyjnych lub markerów powierzchniowych, które byłyby charakterystyczne dla tej populacji, choć ostatnie badania sugeruja, że limfocyty $\operatorname{Tr} 1$ maja na powierzchni antygeny CD49d i LAP. Zaobserwowano, że limfocyty $\operatorname{Tr} 1$, indukowane przez stymulacje CD46, pochodzace od pacjentów z SM, maja mniejsza zdolność do produkcji IL-10 (ASTIER i współaut. 2006). Strategie terapeutyczne, w których następuje indukcja limfocytów $\operatorname{Tr} 1$ produkujących IL10, redukuja stan zapalny w OUN, zmniejszaja aktywację komórek mikrogleju, a także stabilizują barierę krew-mózg, ograniczajacc rekrutację monocytów z krwi obwodowej do OUN (MAYO i współaut. 2016).

Choć SM uważane jest za schorzenie zależne od limfocytów $\mathrm{T}$, to obecność praż̇ków oligoklonalnych $\mathrm{w}$ płynie mózgowo-rdzeniowym chorych oraz wysoka skuteczność terapii anty-CD20, która prowadzi do zmniejszenia liczby limfocytów $B$, świadcza o istotnej roli limfocytów $\mathrm{B}$ w patogene- zie tego schorzenia (GREENFIELD i HAUSER 2018). Zaktywowane limfocyty B można znaleźć w parenchymie mózgu, oponach mózgowych, istocie białej i w płynie mózgowo-rdzeniowym chorych (LOVATO i współaut. 2011). Aktywacja limfocytów B prowadzi do ich przekształcenia się w komórki plazmatyczne produkujace przeciwciała. W trakcie różnicowania limfocytów B dochodzi do pojawiania się i zaniku określonych antygenów powierzchniowych, co umożliwia klasyfikację komórek. Limfocyty B różnia się od komórek plazmatycznych ekspresja CD20, która obecna jest na limfocytach B, brak jej natomiast na komórkach plazmatycznych. Wysoka skuteczność terapeutyczna przeciwcial anty-CD20 sugeruje, że rola limfocytów B w patogenezie SM nie jest tylko zwiazana $z$ produkcja przeciwcial, ale może również zależeć od ich zdolności do prezentacji antygenu czy produkcji cytokin prozapalnych. Potwierdzaja to badania wykazujace, że brak ekspresji MHC II przez limfocyty B, które równocześnie nie produkuja przeciwciał, uniemożliwia indukcję EAE (MOLNARFi i współaut. 2013). U myszy tych obserwuje się również zredukowana odpowiedź limfocytów Th1/Th17 (MOLNARFI i współaut. 2013); co więcej terapia anty-CD20 zmniejsza liczbę limfocytów $\mathrm{T}$ we krwi i płynie mózgowo-rdzeniowym oraz ich $z$ dolność do produkcji prozapalnych IFN- $\gamma$ i IL-17A (BAECHER-ALLAN i współaut. 2018) co sugeruje, że patologiczna rola limfocytów B zwiazana jest $z$ prezentacja antygenu (BAKER i współaut. 2017). Dodatkowo, limfocyty B moga wpływać na profil produkowanych cytokin. Zaobserwowano, że limfocyty B pochodzace od pacjentów z SM produkuja mniej przeciwzapalnej interleukiny IL-10, a więcej GM-CSF (czynnik stymulujący tworzenie kolonii granulocytów i makrofagów), który aktywuje granulocyty do uwalniania prozapalnych oraz promujacych odpowiedź Th1/Th17, interleukin IL-6 i IL-12 (Li i współaut. 2015). Znormalizowany profil cytokinowy limfocytów B, charakteryzujący się wyższymi poziomami IL-10 i niższymi poziomami GM-CSF, obserwowany jest w limfocytach pojawiających się po zmniejszeniu liczby limfocytów $\mathrm{B}$ z zastosowaniem przeciwciał anty-CD20 (BAECHER-ALLAN i współaut. 2018). Warto wspomnieć, że populacje limfocytów B posiadaja właściwości immunoregulacyjne, związane najczęściej ze zdolnościa do produkcji IL-10. Do tej pory nie stwierdzono, czy pacjenci cierpiacy na SM maja zmieniona liczbę limfocytów B regulatorowych (Breg), choć przypuszcza się, że terapia anty-CD20 może przyczyniać się do normalizacji poziomu limfocytów Breg (BAECHER-ALLAN i współaut. 2018). 


\section{IMMUNOPATOGENEZA SM}

Mechanizmy przełamania tolerancji immunologicznej względem antygenów znajdujących się w OUN, prowadzace do aktywacji auto-reaktywnych limfocytów, sa ciagle niejasne. Trzeba mieć na uwadze, że każdy $z$ nas posiada pulę limfocytów rozpoznających auto-antygeny, które, jako nieaktywne, nie stanowia dla nas zagrożenia. Ich aktywacja $z$ wiazana jest $z$ rozpoznaniem antygenu własnego w kontekście sygnałów prozapalnych. W przypadku SM przełamanie tolerancji jest związane $z$ faktem, że antygeny OUN, które sa ukryte przed układem immunologicznym (co określamy mianem uprzywilejowania immunologicznego), staja się nagle widoczne dla tego układu. Oddzielenie OUN od układu immunologicznego możliwe jest dzięki barierze krew-mózg, którą tworzą komórki śródbłonka naczyń krwionośnych wraz z pericytami kapilar, mięśniami gładkimi arterioli oraz astrocytami. Komórki śródbłonka bariery krew-mózg, w przeciwieństwie do śródbłonka na obwodzie, bardzo ściśle do siebie przylegaja, ograniczajac transport substancji i migrację leukocytów krwi do OUN, zapewniając tkance mózgu unikatowe środowisko (SWEENEY i współaut. 2018). Rozluźnienie połaczeń pomiędzy komórkami śródbłonka BBB jest następstwem ich aktywacji i związane jest również $z$ ekspresja cząsteczek regulujacych migrację limfocytów oraz monocytów i neutrofilów do OUN (MINAGAR i ALEXANDER 2003). Zwiększona przepuszczalność $\mathrm{BBB}$, obserwowana za pomoca obrazowania metoda rezonansu magnetycznego (ang. magnetic resonance imaging, MRI), widoczna jest przed wystapieniem upośledzenia funkcji poznawczych w SM (CRAMER i współaut. 2013) i dlatego wykorzystywana jest w diagnostyce $\mathrm{i} \mathrm{w}$ monitorowaniu progresji choroby (MiNAGAR i ALEXANDER 2003).

Sformułowano dwie teorie: wewnętrzna i zewnętrzna, mające na celu wytłumaczenie przyczyn inicjacji autoagresji.

Teoria wewnętrzna sugeruje, iż sygnał inicjujaccy amplifikację odpowiedzi zapalnej pojawia się w OUN. Sygnałem tym może być utrata oligodendrocytów na skutek defektów genetycznych, co może prowadzić do aktywacji komórek mikrogleju. Za teoria ta przemawia fakt, że zmiany tego typu obserwowane sa $\mathrm{w}$ istocie białej bez istnienia jakichkolwiek nacieków komórkowych (HENDERSON i współaut. 2009). Zmiany te najprawdopodobniej promuja uwalnianie antygenów $z$ OUN i ich prezentacje przez komórki prezentujace antygen (ang. antigen-presenting cells, APC), co prowadzi do indukcji antygenowo swoistych limfocytów T.
W teorii zewnętrznej wskazuje się, że aktywacja antygenowo swoistej odpowiedzi immunologicznej następuje poza (zewnętrznie) OUN (MALPASS 2012). Do jej indukcji przyczyniać się może niedostateczna immunosupresja przez limfocyty Treg na skutek defektów w ich liczbie lub aktywności (SCHWARZ i współaut. 2013). Aktywacja auto-reaktywnych klonów limfocytów T i B może również nastapić na drodze mimikry molekularnej lub reakcji krzyżowej (VAUGHAN i współaut. 2014). Zaobserwowano, że limfocyty swoiste dla antygenów OUN maja zdolność do przechodzenia przez BBB (LAROCHELLE i wspó1aut. 2011). Komórki plazmatyczne w OUN produkuja przeciwciała swoiste dla antygenów mieliny oraz antygenów komórek gleju, które na drodze zależnej od fagocytozy lub dopełniacza moga prowadzić do niszczenia posiadajacych je komórek. Znajdujące się $\mathrm{w}$ przestrzeni okołonaczyniowej limfocyty $\mathrm{T}$ $\mathrm{CD}^{+}$i T CD8 ${ }^{+}$migruja do parenchymy mózgu, gdzie ulegaja reaktywacji przez komórki mikrogleju, komórki dendrytyczne i limfocyty B (MOLNARFI i współaut. 2013). Uwalniane cytokiny prozaplane prowadza do dysfunkcji komórek mikrogleju i oligodendrocytów, a także przyczyniaja się do dalszej aktywacji komórek śródbłonka, promując migrację fagocytów, które wydzielaja cytokiny prozapalne, reaktywne formy tlenu i azotu, prowadzac do demielinizacji i uszkodzenia aksonów (FISCHER i współaut. 2012).

\section{ZABURZENIA SNU OBSERWOWANE W SM}

Zaburzenia snu u osób cierpiących na SM, takie jak bezsenność czy zaburzenia rytmu dobowego, sa, przynajmniej częściowo, konsekwencja zaburzeń ruchowych i oddechowych (TACHIBANA i współaut. 1994).

Bezsenność definiuje się jako stan, w którym pacjent, pomimo odpowiednich warunków, nie może zasnać lub podtrzymać snu albo wybudza się wcześniej. $Z$ zaburzeniem tym musi współistnieć co najmniej jeden symptom utrudniajacy funkcjonowanie w ciagu dnia, taki jak: zmęczenie, zaburzenia nastroju, trudności w pracy czy w życiu osobistym, pogorszenie pamięci lub bóle głowy. Bezsenność występuje u około 10-15\% populacji ogólnej (SCHUTTE-Rodin i współaut. 2008), natomiast wśród osób chorych na SM dotyka 40-50\% pacjentów (TACHIBANA i współaut. 1994). U osób chorych na SM niemożność zaśnięcia łączona jest $z$ bólem oraz zaburzeniami nerwicowymi, natomiast trudność w podtrzymaniu snu i bezsenność terminalna sa następstwem nokturii (co najmniej dwukrotne przebudzenie się i oddanie moczu w czasie przeznaczonym na sen) 
(STANTON i współaut. 2006). Przyczyny bezsenności oraz powody zwiększenia jej częstotliwości u chorych na SM nie sa znane.

Najczęstszym zaburzeniem ruchowym, które sprzyja wystąpieniu zaburzeń snu jest zespół niespokojnych nóg (ang. restless leg syndrome, RLS). RLS jest schorzeniem zwiazanym $z$ czuwaniem, w którym pacjent odczuwa niemiłe wrażenia sensoryczne w kończynach, zmuszajace go do poruszenia nimi. Wrażenia te zmniejszaja się wraz $z$ ruchem i narastaja w trakcie bezczynności lub wieczorem (HENING i współaut. 2007). RLS dotyka $2-18 \%$ ogólnej populacji oraz 13-37\% osób chorych na SM (BRASS i współaut. 2010). Czynnikami, które zwiększaja prawdopodobieństwo pojawienia się zaburzenia sa wiek, mimowolne ruchy nóg przed zaśnięciem oraz pierwotnie-postępująca postać SM. Znaczna część badań wskazuje również na istnienie zależności pomiędzy ciężkością objawów SM oraz skłonnościa do wystapienia RLS (BRASS i współaut. 2010). Do tej pory nie zidentyfikowano czynników, które równocześnie promowałyby rozwój SM i RLS, wydaje się zatem, że pojawienie się RLS jest następstwem uszkodzenie OUN w SM (MANCONI i współaut. 2008).

Zaburzenia snu obserwowane sa również jako następstwo zaburzeń oddychania w czasie snu, takich jak: bezdech senny zwiąany ze zwężeniem górnych dróg oddechowych (zespół obturacyjnego bezdechu sennego), bezdech senny nie zwiazany ze zwężeniem górnych dróg oddechowych (ośrodkowy bezdech senny) lub klątwa Odyny, która odnosi się do zespołu wrodzonej ośrodkowej hipowentylacji (pierwotna hipowentylacja pęcherzykowa, CCHS). Najczęściej występujaccym zaburzeniem jest zespół obturacyjnego bezdechu sennego, na który cierpi 2-4\% populacji osób dorosłych. Wśród osób cierpiacych na SM częstość schorzenia jest zróżnicowana i może sięgać nawet do 58\% (BRASS i współaut. 2010, KAMINSKA i współaut. 2012). Obecnie brak jest badań, które tłumaczyłyby zależność pomiędzy SM a zaburzeniami oddychania w czasie snu, choć przypuszcza się, że może odgrywać tu rolę spastyczność prowadząca do rozluźnienia mięśni krtani oraz obecność płytek (obszarów zapalno-demielinizacyjnych) wpływajacych na aktywność neuronów motorycznych.

Zaburzenia rytmu dobowego dotykaja zegara biologicznego sprawiając, że nasz wewnętrzny rytm ulega desynchronizacji $z \quad 24$ godzinnym rytmem czuwania i snu. Nieprawidłowości u osób młodych dotyczą opóźnienia fazy snu, a u osób starszych przyśpieszenia fazy snu. Częstość zaburzeń rytmu dobowego w populacji ogólnej nie jest znana, natomiast częstość zaburzeń w popula- cji pacjentów $Z$ SM jest silnie zróżnicowana (BRAss i współaut. 2010). Wydaje się, że obecność zaburzeń rytmu okołodobowego u pacjentów cierpiacych na SM może być zwiazana $z$ obecnością zmian demielinizacyjnych w jądrach nadskrzyżowaniowych, które kieruja rytmem czuwania i snu.

Patofizjologia zaburzeń snu w następstwie SM jest słabo poznana. Brak jest badań łączacych zmiany w OUN w następstwie SM $z$ określonymi typami zaburzeń snu. Wiadomo jednak, że zarówno sen, jak SM zwiazane sa $z$ układem immunologicznym. W płynie mózgowo-rdzeniowym osób chorych na SM stwierdzono podwyższone poziomy prozapalnych IL-1 i TNF-a (HAUSER i wspó1aut. 1990). Podwyższone poziomy TNF-a i IFN-y obserwowane u pacjentów cierpiacych na SM zwiazane są ze zmęczeniem, któremu często towarzyszą zaburzenia snu. $Z$ drugiej strony, zwiększone poziomy IL-1 i TNF-a obserwowane są także $u$ chorych cierpiących na zespół obturacyjnego bezdechu sennego, deprywację snu i depresję (BRAss i wspó1aut. 2010).

Zaburzenia snu w stwardnieniu rozsianym sa rzadko rozpoznawanym problemem, choć przeprowadzone do tej pory badania wskazuja, że problem dotyka 43-67\% chorych. Co więcej, zaburzenia snu dotycza chorych na SM cztery razy częściej niż osoby zdrowe (BAMER i współaut. 2008, ВøE LUNDE i współaut. 2012, GARLAND i współaut. 2017) i obserwowane sa u 78\% kobiet i 53\% mężczyzn cierpiących na SM (BøE LUNDE i współaut. 2012), a ich wystapienie zwiąane jest $z$ zaburzeniami współistniejacymi z SM (MERLINo i współaut. 2009, BøE LundE i współaut. 2012). U pacjentów z SM bardzo często rozwija się depresja i towarzyszace jej zaburzenia snu (BøE LUNDE i współaut. 2012). Zaobserwowano również, że stosowanie immunoterapii $\mathrm{w}$ postaci interferonu beta (IFN- $\beta$ ), octanu glatirameru, $\mathrm{u}$ pacjentów $\mathrm{z}$ rzutowo-remisyjna postacia choroby, spowodowało wystapienie zaburzeń snu u 2/3 chorych w noc po podaniu leku (MENDOZZI i współaut. 2010). Poprawę snu w trakcie immunoterapii osiagano przez przesunięcie godziny podania IFN- $\beta$ $z$ wieczornej na poranna (NADJAR i współaut. 2011). Zaburzenia snu w SM łączą się również ze współwystępującym zmęczeniem, które związane jest $z$ występowaniem senności $w$ ciagu dnia, wycieńczeniem i pogorszeniem symptomów choroby. Zmęczenie wystapiło średnio u $85 \%$ chorych w pierwszym roku choroby, a w kolejnych latach dotknęło nawet 95\% chorych (PATEJDL i współaut. 2016) i w znaczący sposób upośledziło funkcjonowanie pacjentów $z$ SM, a także zwiększyło ryzyko wystapienia depresji w tej populacji. 


\section{TERAPIA SM}

Obecnie nie ma leku, który całkowicie przeciwdziałałby zmianom neurodegeneracyjnym, będacych następstwem stanu zapalnego w OUN. Wiedza na temat patomechanizmów, leżących u podstaw SM, pozwoliła na stworzenie leków modyfikujacych przebieg choroby (ang. disease-modifying therapies, DMTs), których celem jest ograniczenie rozwoju już istniejących płytek i przeciwdziałanie powstawaniu nowych.

W 1993 r. zarejestrowano pierwsza terapię RRMS, która opierała się na aplikacji interferonu (IFN)- $\beta 1 \mathrm{~b}$. Interferony to grupa białek naturalnie produkowanych przez organizm, uczestniczacych w odpowiedzi immunologicznej $\mathrm{w}$ stosunku do praktycznie każdego antygenu. IFN- $\beta$ należy to interferonów typu I, które $\mathrm{w}$ przeciwieństwie do interferonów typu II, posiadaja funkcje przeciwzapalne, gdyż zmniejszaja ekspresję MHC II i przesuwaja profil odpowiedzi immunologicznej $z$ prozapalnego Th1/Th17 na przeciwzapalny, związany ze wzmożona produkcja IL-10 (KIESEIER 2011). Badania kliniczne III fazy na przestrzeni 2 lat wykazały, że terapia podskórna IFN- $\beta 1 \mathrm{~b}$ redukuje o $34 \%$ całkowita liczba nawrotów w stosunku do grupy kontrolnej oraz ogranicza o około $50 \%$ ryzyko pojawienia się nowych zmian na przestrzeni jednego roku (STUDY GROUP 1993). W terapii wykorzystuje się również IFN- $\beta 1$ a podawany domięśniowo lub śódskórnie. Jednak terapia interferonami może doprowadzić do immunizacji organizmu interferonem, powodujac wytworzenie przeciwciał neutralizujacych podawany preparat, co skutkuje obniżeniem poziomu interferonu $\mathrm{w}$ organizmie, zmniejszając skuteczność terapii.

Kolejnym podejściem terapeutycznym, zatwierdzonym do terapii RRMS, jest octan glatirameru (ang. glatiramer acetate, GA), podawany podskórnie. GA to mieszanina peptydów o różnej długości, składających się z czterech aminokwasów: L-glutaminy, L-alaniny, L-tyrozyny i L-lizyny, działajacych jak analog MBP. Mechanizm działania GA nie jest do końca poznany. Wydaje się, że po podaniu GA dochodzi do jego przetworzenia i prezentacji przez APC naiwnym limfocytom $\mathrm{T}$, które następnie różnicuja się w kierunku limfocytów Th2 (AHARONI i współaut. 1997). Odpowiedzi Th1- i Th2-zależne sa ze soba sprzężone i moga wzajemnie się hamować. Zaobserwowano, że transfer limfocytów Th2 indukowanych podaniem GA hamuje rozwój EAE u myszy, co najprawdopodobniej jest zwiazane $z$ tym, że indukowane limfocyty Th2 reaguja krzyżowo $z$ antygenem MBP i produkuja cytokiny o aktywności przeciwzapalnej, takie jak IL-4 i IL-10. Cytokiny te, jako „przygodny widz”, będa hamować Th1-zależna odpowiedź immunologiczną w OUN osób chorych na SM (AHARONI i współaut. 1997). Terapia GA jest tak samo skuteczna jak terapia IFN- $\beta$, ale nie niesie ze soba ryzyka wytworzenia przeciwciał neutralizujacych (Mikol i współaut. 2008).

Kolejna grupa środków leczniczych wykorzystywanych $\mathrm{w}$ terapii RRMS sa przeciwciała monoklonalne (mAb). Pierwszym przeciwciałem monoklonalnym zatwierdzonym w terapii RRMS jest Natalizumab. Migracja leukocytów krwi do OUN wymaga przejścia przez śródbłonki bariery krew-mózg. Migracja leukocytów odbywa się dzięki interakcji antygenu VCAM-1 (ang. vascular cell adhesion molecule 1), znajdującego się na śródbłonkach BBB, $z$ integryna a $4 \beta 1$, znajdujaca się na leukocytach. Integryna a $4 \beta 1$ oddziałuje również ze znajdująca się w macierzy zewnattrzkomórkowej fibronektyna, wpływając na czas życia i aktywację limfocytów. Natalizumab jest humanizowanym przeciwciałem monoklonalnym rozpoznającym integrynę a4. Podanie Natalizumabu będzie zatem uniemożliwiać interakcję pomiędzy leukocytami krwi a komórkami śródbłonków naczyń, uniemożliwiając przejście leukocytów przez $\mathrm{BBB}$, prowadzac tym samym do ograniczenia stanu zapalnego w mózgu (RANSOHOFF 2007, SELLEBJERG i współaut. 2016). Natalizumab zmniejsza o $68 \%$ ryzyko nawrotu RRMS w ciagu jednego roku, a także o 83\% ryzyko pojawienia się nowych lub powiększających się zmian (Polman i współaut. 2006). Pomimo wysokiej skuteczności, terapia Natalizumabem stosowana jest $\mathrm{u}$ pacjentów $\mathrm{z}$ bardzo aktywnym klinicznie lub radiologicznie SM $z$ racji licznych i niebezpiecznych skutków ubocznych. Efekty uboczne sa następstwem immunosupresji, która może przyczynić się do aktywacji wirusa John Cunningham (JC), który prowadzi do demielinizacji mózgu (ang. progressive multifocal leukoencephalopathy, PML), kończącej się śmiercia u 20\% pacjentów $z$ PML. Immunosupresja zwiększa również nieznacznie ryzyko wystapienia zapalenia płuc i infekcji wirusem opryszczki zwykłej (ang. Herpes simplex virus, HSV). Dodatkowo, u około $1 \%$ pacjentów obserwuje się rozwój nadwrażliwości w stosunku do Natalizumab (RANSOHOFF 2007).

Kolejnym mAb, które znalazło zastosowanie w terapii RRMS jest Rituximab (RTX), który jest przeciwciałem chimerycznym ludzko-mysim rozpoznajacym antygen CD20, znajdujacy się na znacznej części limfocytów B (nie znajduje się na komórkach pamięci). Przyłączenie się wspomnianych mAb do antygenu CD20 prowadzi do deplecji limfocytów B na drodze zależnej od dopełniacza we krwi, a także, choć w mniejszym zakre- 
sie, w płynie mózgowo-rdzeniowym (INEICHEN i współaut. 2020). W pierwszym badaniu klinicznym z RTX zaobserwowano 91\% redukcje liczby zmian ogniskowych Gad+ oraz statystycznie istotna redukcję liczby rzutów (HAUSER i współaut. 2008). Jednak jego aplikacja zwiększa ryzyko infekcji, generuje powstanie przeciwciał neutralizujacych oraz reakcji niepożądanych zwiazanych $\mathrm{z}$ podaniem (INEICHEN i współaut. 2020).

Innym zwiazkiem, wykorzystywanym w terapii SM jest Fingolimod, czyli sfingozyno-1-fosforan. Lek podawany jest doustnie. W organizmie ulega przekształceniu $\mathrm{w}$ fosforan fingolimodu, który działa jak analog i wiąże się do części receptorów dla sfingozyno-1-fosforanu, powodując ich internalizacje, a tym samym zmniejszenie ekspresji. Receptory te obecne na limfocytach $\mathrm{T}$ i $\mathrm{B}$ reguluja uwalnianie limfocytów $z$ węzłów chłonnych i ich migrację do krwioobiegu. Aplikacja Fingolimodu zmniejsza poziom krażaacych limfocytów, co doprowadza do redukcji stanu zapalnego w OUN. W badaniach klinicznych stwierdzono, że dawki $0,5 \mathrm{mg}$ i 1,25 mg Fingolimodu zmniejszaja ryzyko progresji niepełnosprawności zwiazanej ze schorzeniem odpowiednio o $70 \%$ i $65 \%$. $Z$ jego aplikacja zwiazane sa jednak skutki uboczne, takie jak: bradykardia, blok przedsionkowo-komorowy, umiarkowane nadciśnienie i zwiększone ryzyko infekcji (KAPPOS i współaut. 2010).

Jednym $z$ najnowszych leków jest fumaran dimetylu, zwiazek pokrewny do kwasu fumarowego, wykorzystywanego w terapii łuszczycy. Zwiazek ten wykazuje działanie antyoksydacyjnie i, wpływajac na szlaki sygnałowe zależne od statusu oksydacyjnego, może zmieniać profil syntetyzowanych cytokin $\mathrm{z}$ Th1 na Th2 (WIERINCKX i współaut. 2005). Badania kliniczne wykazały, że liczba aktywnych zmian u pacjentów $z$ RRMS otrzymujacych fumaran dimetylu, jest o $69 \%$ mniejsza w porównaniu do grupy kontrolnej. Zwiazek ten zmniejsza również liczbę rzutów $i$ jest stosunkowo dobrze tolerowany.

Stwardnienie rozsiane jest schorzeniem, w którym układ immunologiczny rozpoznaje antygeny organizmu znajdujące się w OUN. Przedstawione powyżej leki nie wykazuja swoistości antygenowej, dlatego ich aplikacja modyfikuje odpowiedź immunologiczna limfocytów o różnych swoistościach, również tych zaangażowanych $\mathrm{w}$ odporność przeciwzakaźna. Dodatkowo, ich aplikacja niesie ze soba ryzyko wystapienia licznych skutków ubocznych, czasami bardzo poważnych, co sprawia, że stosowanie niektórych $z$ nich ograniczone jest do bardziej zaawansowanych postaci schorzenia. Metoda terapeutyczna, której stosowanie nie niesie ze soba wad posia- danych przez przedstawione terapeutyki, jest przezskórna aplikacja antygenów mieliny.

\section{SKÓRA JAKO MIEJSCE APLIKACJI LEKÓW}

Pierwsze próby naskórnej aplikacji leków datuje się na 2000 r. przed nasza erą. W Chinach mieszanina wyciagu $\mathrm{z}$ ziół $\mathrm{w}$ formie pasty nakładana była na kawałek materiału, który następnie mocowany był na zmieniona chorobowo skórę. W czasach nowożytnych, około 200 roku naszej ery, terapię zmian skórnych poprzez aplikacje wyciagów $\mathrm{z}$ ziół $\mathrm{w}$ formie kremu stosował Galen. $\mathrm{Z}$ kolei w XV w. maść zawierająca rtęć wykorzystywano do leczenia kiły (patrz SzczEPANIK i MAJEWSKA-SZCZEPANIK 2016). Pierwsze próby naskórnej aplikacji leków do leczenia systemowego podjęto w latach 40. XX w. Zondek, wykorzystując maść zawierajaca antyseptyczny chloroxylenol, leczył zakażenie układu moczowo-płciowego. W latach 70. zoptymalizowano sposób naskórnej aplikacji leków przez zastosowanie plastra, który pozwala na kontrolę dawki podawanej substancji. Metoda ta jest obecnie powszechnie wykorzystywana w celu aplikacji hormonów, środków przeciwbólowych czy leków na chorobę lokomocyjna (SZCZEPANIK i MAJEWSKA-SZCZEPANIK 2016).

Najistotniejszym aspektem naskórnej aplikacji leków jest to, że taka droga podania pozwala na ominięcie obróbki enzymatycznej lub chemicznej podawanej substancji leczniczej w układzie pokarmowym, co jest szczególnie istotne w przypadku leków, będących peptydami lub białkami. Problematyczna, w trakcie naskórnej aplikacji substancji leczniczych, wydaje się być „zasada 500 Daltonów (Da)", która wskazuje, że substancje, których cząsteczki przekraczaja rozmiar $500 \mathrm{Da}$, a sa nimi białka i peptydy, nie przechodzą przez naskórek (Bos i MEINARDI 2000). Ograniczenie penetracji naskórka do $500 \mathrm{Da}$ jest jednak tylko pozornie problemem, gdyż aplikacja plastra na skórę prowadzi do zwiększonej perspiracji, która rozmiękcza naskórek i umożliwia penetrację peptydów i białek (TAN i współaut. 2010, Mondoulet i współaut. 2010). Dodatkowo, by ułatwić substancjom penetrację naskórka, można stosować dermabrazję za pomoca taśmy, liposomów, transferomów lub plastrów $z$ mikroigiełkami (SzCZEPANIK i MAJEWSKA-SZCZEPANIK 2016). Elementem, o którym trzeba jednak pamiętać w trakcie tych procedur jest to, że skóra jest narzadem, w którym znajduja się komórki układu odpornościowego, dlatego dochodzi tam do indukcji odpowiedzi immunologicznej o profilu zależnym od otrzymywanych sygnałów. 
Metoda dermabrazji może wpływać na profil cytokinowy i determinować rodzaj indukowanej odpowiedzi immunologicznej. Przykładowo, dermabrazja za pomoca taśmy zwiększa produkcje cytokin przeciwzapalnych, takich jak IL-25, IL-33 oraz TSLP, i wspomaga indukcje odpowiedzi typu Th2 (SzCZEPANIK i MAJEWSKA-SZCZEPANIK 2016). Bardziej intensywne uszkodzenie naskórka będzie prowadzić do produkcji cytokin prozapalnych, takich jak TNF-a oraz IL-6, promujacych odpowiedź typu Th1 (SWAMY i współaut. 2010).

\section{SKÓRA JAKO MIEJSCE INDUKCJI IMMUNOSUPRESJI}

Obserwacje poprzedzające badania nad skóra jako miejscem indukcji immunosupresji sugerowały, że naskórna (EC) aplikacja antygenów białkowych indukuje syntezę cytokin typu Th2, takich jak IL-4 i IL-13, które działaja hamujacco na produkcję cytokin przez limfocyty Th1, a tym samym moga hamować odpowiedź immunologiczna z udziałemtych limfocytów (HERRICK i współaut. 2000). W naszym laboratorium przeprowadziliśmy ocenę EC aplikacji antygenów białkowych jako metody indukcji tolerancji, $z$ wykorzystaniem reakcji nadwrażliwości kontaktowej (CS), która jest mysim modelem alergicznego kontaktowego zapalenia skóry, obserwowanego u człowieka. Reakcja CS przebiega $z$ udziałem limfocytów Th1/Th17 lub Tc1 i klasyfikowana jest jako reakcja nadwrażliwości typu IV, która leży u podstaw wielu schorzeń autoimmunizacyjnych. Reakcja CS indukowana jest przez aplikację haptenu na skórę brzucha. Wywołanie reakcji następuje po czterech dniach, poprzez aplikację roztworu haptenu na skórę uszu. Intensywność reakcji zapalnej ocenia się makroskopowo, przez pomiar przyrostu grubości małżowiny usznej. Stosując TNP-Cl jako hapten można wywołać Th1 zależna reakcję CS. Aplikacja antygenu białkowego w postaci immunoglobulin skoniugowanych $z$ TNP (TNP-Ig) w postaci opatrunku $z$ gazy na skórę grzbietu, na tydzień przed indukcja reakcji CS, prowadziła do zahamowania reakcji CS. Inhibicja reakcji CS po naskórnej aplikacji antygenu jest wynikiem działania unikatowej populacji limfocytów $\mathrm{TCRa}^{+} \mathrm{CD} 4^{+} \mathrm{CD} 8^{+}$, które uwalniaja TGF- $\beta$ (SzCZEPANIK i wspó1aut. 2005). Następnie zaobserwowaliśmy, że EC aplikacja antygenu również hamuje reakcje CS zależna od limfocytów $\mathrm{CD}^{+} \mathrm{Tc} 1$ $\mathrm{w}$ odpowiedzi na hapten $\mathrm{DNFB}^{+}$(MAJEWSKA-SzCZEPANIK i współaut. 2012 a). Wykazaliśmy bowiem, że aplikacja antygenu białkowego DNP-BSA poprzedzajaca immunizację DNFB, zahamuje reakcję CS w skórze za pośrednictwem limfocytów regulatorowych
(Treg) o fenotypie $\mathrm{TCRa}^{+} \mathrm{CD}^{+} \mathrm{CD} 25^{+} \mathrm{FoxP}^{+}$ (MAJEWSKA-SzCZEPANIK i współaut. 2012 b). W przeciwieństwie do reakcji CS indukowanej TNP-Cl, supresja w odpowiedzi na DNFB nie była zwiazana $z$ produkcja cytokin przeciwzapalnych, ale wymagała bezpośredniego kontaktu między komórkami $\mathrm{T}$ efektorowymi i Treg za pośrednictwem cząsteczki CTLA-4 (ZEMELKA-WIĄCEK i współaut. 2012). Wyniki uzyskane przez aplikację antygenu białkowego $\mathrm{w}$ formie opatrunku $\mathrm{z}$ gazy potwierdziliśmy stosując codzienna EC aplikację antygenu białkowego, zawieszonego w kremie, przed indukcja reakcji CS zależnej od limfocytów Th1 (PTAK i współaut. 2002).

Wyniki uzyskane $\mathrm{w}$ modelu reakcji CS zależnej od limfocytów Th1 i Tc1 sugerowały, że zahamowanie reakcji zapalnej na obwodzie po naskórnej aplikacji antygenu białkowego, może być bardziej uniwersalnym fenomenem immunologicznym, dajacym się zastosować w ograniczaniu reakcji zapalnej w innych schorzeniach, u podstaw których leży reakcja komórkowa $z$ udziałem limfocytów $T$. Stosujac mysi model reumatoidalnego zapalenia stawów, tj. kolagenowe zapalenie stawów (CIA), zaobserwowaliśmy, że naskórna aplikacja kolagenu przed indukcją CIA znacznie łagodzi przebieg choroby (MARCIŃSKA i współaut. 2015, MARCIŃSKA i współaut. 2016). Co więcej, naskórna aplikacja kolagenu w momencie pojawienia się pierwszych objawów schorzenia była efektywna metoda terapeutyczna, która redukowała intensywność stanu zapalnego w stawach (MARCIŃSKA i współaut. 2015). Podobnie, EC aplikacja antygenu białkowego przed wywołaniem zapalenia jelit indukowanego haptenem przez doodbytnicza aplikację haptenu TNBS w roztworze etanolu, ograniczyła intensywności schorzenia (MAJEWSKA-SZCZEPANIK i współaut. 2012c).

Ocenę efektywności naskórnej aplikacji antygenu białkowego do ograniczania stanu zapalnego przeprowadziliśmy również w mysim modelu eksperymentalnego zapalenia rdzenia kręgowego i mózgu (EAE) (SzCZEPANIK i współaut. 2005, TUTAJ i SzCZEPANIK 2007, MAJEWSKA i współaut. 2007). Naskórna aplikacja białka zasadowego mieliny (MBP) przed indukcja EAE opóźniła w czasie wystapienie choroby, a także znacznie łagodziła jej przebieg (SzCZEPANIK i współaut. 2005). Zahamowanie to korelowało $z$ mniejszym naciekiem OUN przez komórki jednojądrzaste oraz brakiem widocznych zmian patologicznych w skrawkach tkankowych (MAJEWSKA i współaut. 2007). Obserwowana supresja była wynikiem działania komórek TCRa ${ }^{+} \mathrm{CD}^{+}{ }^{+} \mathrm{CD}^{+}$uwalniajacych TGF- $\beta$ (TUTAJ i SzCZEPANIK 2007). Z klinicznego punktu widzenia bardziej istotna była obserwacja, iż EC aplikacja MBP w chwili pojawienia się 
pierwszych objawów choroby znamiennie hamowała rozwój i przebieg choroby.

Skuteczność naskórnej aplikacji antygenów białkowych w modelach zwierzęcych ocenialiśmy również we współpracy z klinicystami (JURYŃCZYK i współaut. 2010, WALCZAK i współaut. 2013). W trwającym rok badaniu klinicznym, pacjentom cierpiącym na RRMS podawano na przedramie plaster zawierajacy mieszaninę peptydów mielinowych, takich jak MBP, PLP oraz MOG. Strategia ta zredukowała o $65,5 \%$ liczbę zmian ogniskowych $\mathrm{Gd}^{+}$ oraz statystycznie zmniejszyła liczbę rzutów (WALCZAK i współaut. 2013). Aplikacja peptydów zwiazana była $\mathrm{z}$ aktywacja komórek Langerhansa $\mathrm{w}$ skórze, pojawieniem się populacji komórek dendrytycznych $\mathrm{z}$ ziarnistościami w lokalnych węzłach chłonnych, wzrostem uwalniania przeciwzapalnej IL-10 oraz zahamowaniem sekrecji prozapalnego IFN- $\gamma$ przez komórki jednojądrzaste krwi obwodowej (PBMC) (JURYŃCZYK i współaut. 2010). Z powyżej opisanymi zmianami $\mathrm{w}$ profilu odpowiedzi immunologicznej korelowała zredukowana proliferacja limfocytów T krwi obwodowej. Zastosowana terapia była dobrze tolerowana i nie zaobserwowano poważnych skutków ubocznych (WALCZAK i współaut. 2013).

Przedstawione badania sugerują, że naskórna terapia $\mathrm{z}$ zastosowaniem mieszaniny peptydów osłonki mielinowej jest skuteczna i nieobarczona ryzykiem poważnych skutków ubocznych potencjalna terapia RRMS.

$$
\text { Straeszczenie }
$$

Stwardnienie rozsiane (łac. sclerosis multiplex, SM) to schorzenie autoimmunologiczne, w którym limfocyty, autoreaktywne względem antygenów komórek nerwowych, naciekają ośrodkowy układ nerwowy i prowadza do jego uszkodzenia. Stan ten doprowadza u osoby chorej do postępującego w sposób ciagły lub rzutami, pogarszania się funkcji fizycznych, poznawczych, emocjonalnych oraz społecznych. U 43-67\% chorych na SM obserwuje się nieprawidłowości związane ze snem, polegające na bezsenności, zaburzeniach rytmu dobowego, oraz pojawiające się $\mathrm{w}$ następstwie zaburzeń ruchowych i oddychania. Zaburzenia te moga pogarszać przebieg SM, zaś SM może pogarszać i zwiększać prawdopodobieństwo wystapienia zaburzeń snu. Ta dwukierunkowa zależność zwiazana jest $z$ istotna rola układu immunologicznego zarówno $\mathrm{w}$ patogenezie SM, jak i zaburzeń snu. W artykule przeglądowym przedstawiamy najnowsze informacje dotyczace etiologii i roli układu immunologicznego w SM oraz immunopatomechanizmu tego schorzenia, zwracajac szczególną uwage na współistniejące zaburzenia snu. W dalszej części omawiane sa metody terapeutyczne SM, ze szczególnym uwzględnieniem naskórnej aplikacji antygenu białkowego, które oprócz ograniczenia postępu choroby potencjalnie moga prowadzić do zmniejszenia współistniejących zaburzeń snu.

\section{LITERATURA}

Aharoni R., Teitelbaum D., Sela M., Arnon R., 1997. Copolymer 1 induces $T$ cells of the $T$ helper type 2 that crossreact with myelin basic protein and suppress experimental autoimmune encephalomyelitis. Proc. Natl. Acad. Sci. USA 94, 10821-10826.

Astier A. L., Meiffren G., Freeman S., Hafler D. A., 2006. Alterations in CD46-mediated $\operatorname{Tr} 1$ regulatory $T$ cells in patients with multiple sclerosis. Version 2. J. Clin. Invest. 116, 3252-3257.

BABBE H., RoERs A., WAISMAN A., LASSMANN H., Goebels N., Hohlfeld R., Friese M., SCHRÖDER R., DECKERT M., SCHMIDT S., RAVID R., RAJEWSKY K., 2000. Clonal expansions of $C D 8(+) T$ cells dominate the $T$ cell infi ltrate in active multiple sclerosis lesions as shown by micromanipulation and single cell polymerase chain reaction. J. Exp. Med. 192, 393-404.

BAECHER-Allan C., KASKOW B.J., WeineR H. L., 2018. Multiple sclerosis: mechanisms and immunotherapy. Neuron 97, 742-768.

Baker D., Marta M., Pryce G., Giovannoni G., SCHMIERER K., MEMORY B., 2017. Cells are major targets for effective immunotherapy in relapsing multiple sclerosis. EBioMedicine 16, 41-50.

BAMER A. M., Johnson K. L., AMTMANN D., KRAFT G. H., 2008. Prevalence of sleep problems in individuals with multiple sclerosis. Mult. Scler. 14, 1127-1130.

Becher B., Durell B. G., Noelle R. J., 2002. Experimental autoimmune encephalitis and inflammation in the absence of interleukin-12. J. Clin. Invest. 110, 493-497.

Bhela S., KempSEll C., MANOHAR M., DOMINGUEZ-Villar M., GRIFFin R., BHATT P., KIVISAKK-WEBB P., FUHLBRIGGE R., KUPPER T., Weiner H., BAECHER-Allan C., 2015. Nonapoptotic and extracellular activity of granzyme $B$ mediates resistance to regulatory $T$ cell (Treg) suppression by HLA-DR-CD25hiCD127lo Tregs in multiple sclerosis and in response to $I L-6$. J. Immunol. 194, 2180-2189.

BøE LUNDE H. M., AAE T. F., INDREVÅG W., AARSETH J., BJORVATN B., MYHR K. M., BØ L., 2012. Poor sleep in patients with multiple sclerosis. PLoS One 7, doi: 10.1371/journal. pone.0049996.

Bos J. D., MEINARd M. M., 2000. The 500 Dalton rule for the skin penetration of chemical compounds and drugs. Exp. Dermatol. 9, $165-169$

Brass S. D., Duquette P., ProulX-Therrien J., AUERBACH S., 2010. Sleep disorders in patients with multiple sclerosis. Sleep Med. Rev. $14,121-129$

BRUNKOW M. E., JEFFERY E. W., HJERRILD K. A., Paeper B., Clark L. B., Yasayko S. A., WILKINSON J. E., GALAS D., ZIEGLER S. F., RAMSDELL F., 2001. Disruption of a new forkhead/winged-helix protein, scurfin, results in the fatal lymphoproliferative disorder of the scurfy mouse. Nat. Genet. 27, 68-73.

CRAMER S. P., SimONSEN H., FREDERIKSEN J. L., ROSTRUP E., LARSSON H. B. W., 2013. Abnor mal blood-brain barrier permeability in normal appearing white matter in multiple sclerosis investigated by MRI. Neuroimage Clin. 4, $182-189$.

FARH K. K.-H., MARSON A., ZhU J., KLEINEWIETFELD M., Housley W. J., BeIK S., SHORESH N., WHITTON H., RYAN R. J. H., SHISHKIN A. A., Hatan M., CarRasco-Alfonso M. J., MaYER D., LuCKey C. J., Patsopoulos N. A., DE JAGER P. L., KUCHROO V. K., EPSTEIN C. B., DAlY M. J., HAFleR D. A., BRADley E., BERNSTEIN B. E., 2015. Genetic and epigenetic fine 
mapping of causal autoimmune disease variants. Nature 518, 337-343.

Fischer M. T., SHARMA R., LiM J. L., HAIDER L., Frischer J. M., DREXHAGE J., MAHAD D., BRADL M., VAN HORSSEN J., LASSMANN H., 2012. NADPH oxidase expression in active multiple sclerosis lesions in relation to oxidative tissue damage and mitochondrial injury. Brain 135, 886-899.

Fischer M.T., WimMer I., HÖFTBERGer R., GerLACH S., HAIDER L., ZRZAVY T., HAMETNER S., MAHAD D., Binder C. J., KRUMBhOlZ M., Bauer J., Bradl M., Lassmann H., 2013. Disease-specific molecular events in cortical multiple sclerosis lesions. Brain 136, 1799-1815.

GARLAND S. N., SCURREY S. R. M., PlOUGHMAN M., 2017. Health, lifestyle and aging with MS canadian consortium. factors associated with poor sleep in older adults with multiple sclerosis. Int. J. Behav. Med. 24, 937-945.

GREenfield A. L., HaUser S. L., 2018. B-cell therapy for multiple sclerosis: entering an era. Ann. Neurol. 83, 13-26.

Haines J. L., Terwedow H. A., Burgess K., PeriCAK-VANCE M. A., RIMMLER J. B., MARTIN E. R., OKSENBERG J. R., LINCOLN R., ZHANG D. Y., BANATAO D. R., GatTo N., GoOdKIN D. E., HAUSER S. L., 1998. Linkage of the MHC to familial multiple sclerosis suggests genetic heterogeneity. The Multiple Sclerosis Genetics Group. Hum. Mol. Genet. 7, 1229-1234.

Hauser S. L., Bhan A. K., Gilles F., Kemp M., KERR C., WEINER H. L., 1986. Immunohistochemical analysis of the cellular infiltrate in multiple sclerosis lesions. Ann. Neurol. 19, 578-587.

Hauser S. L., Doolittle T. H., Lincoln R., BRown R. H., DinaRello C. A., 1990. Cytokine accumulations in CSF of multiple sclerosis patients: frequent detection of interleukin-1 and tumor necrosis factor but not interleukin-6. Neurology 40, 1735-1739.

Hauser S. L., Waubant E., ARnold D. L., VolLMER T., ANTEL J., FOX R. J., BAR-OR A., PANZARA M., SARKAR N., AGARWAL S., LANGERGOUld A., SMITH C. H., HERMES TRIAl GROUP, 2008. B-cell depletion with rituximab in re lapsing-remitting multiple sclerosis. N. Engl. J. Med. 358, 676-688.

HaVRdová E., BElova A., Goloborodko A., TisSERANT A., WRIGHT A., WALlSTROEM E., GARREN H., MAGUIRE R. P., Johns D. R., 2016 Activity of secukinumab, an anti-IL-17A antibody, on brain lesions in RRMS: results from a randomized, proof-of-concept study. J. Neurol. 263, 1287-1295.

Hedström A. K., Åkerstedt T., Olsson T., AlFREDSSON L., 2015. Shift work influences multiple sclerosis risk. Mult. Scler. 21, 11951199.

Henderson A. P., BARNetT M. H., PARRATT J. D., PRINEAS J. W., 2009.Multiple sclerosis: distribution of inflammatory cells in newly forming lesions. Ann Neurol. 66, 739-753.

Hening W. A., Allen R. P., Chaudhuri K. R., HORNYAK M., LEE H. B., WINKELMAN J., YOAKUM R., 2007. Clinical significance of RLS. Mov. Disord. 22 (Suppl. 18), S395-S400.

Herrick C. A., Macleod H., Glusac E., Tigelaar R. E., BOTTOMLY K., 2000. Th2 responses induced by epicutaneous or inhalational protein exposure are differentially dependent on IL-4. J. Clin. Invest. 105, 765-775.

HOHLFEld R., DORNMAIR K., MEINL E., WEKERLE H., 2016. The search for the target antigens of multiple sclerosis, part 1: autoreactive CD4+
$T$ lymphocytes as pathogenic effectors and therapeutic targets. Lancet Neurol. 15, 198209.

Hori S., Haury M., Coutinho A., Demengeot J., 2002. Specificity requirements for selection and effector functions of $C D 25+4+$ regulatory $T$ cells in anti-myelin basic protein $T$ cell receptor transgenic mice. Proc. Natl. Acad. Sci. USA 99, 8213-8218.

Huber M., Heink S., Pagenstecher A., Reinhard K., RitTer J., ViseKruna A., GuRAlNiK A., BOLLig N., Jeltsch K., Heinemann C., WitTmanN E., Buch T., Prazeres da Costa O., Brüstle A., BRENNER D., MAK T.W., MitTRÜCKER H.W. TACKENBERG B. KAMRADT T. LOHOFF M., 2013. IL-17A secretion by CD8+ $T$ cells supports Th17-mediated autoimmune encephalomyelitis. J. Clin. Invest. 123, 247-260.

Ineichen B. V., Moridi T., GRANBerg T., PIEHL F., 2020. Rituximab treatment for multiple sclerosis. Mult. Scler. 26, 137-152.

JURYŃCZYK M., WALCZAK A., JUREWICZ A., JESIONEK-KUPNICKA D., SZCZEPANIK M., SELMAJ K., 2010. Immune regulation of multiple sclerosis by transdermally applied myelin peptides. Ann. Neurol. 68, 593-601.

Kaminska M., Kimoff R. J., BenedetTi A., RoBinSON A., BAR-OR A., LAPIERRE Y., SCHWARTZMAN K., TROJAN D. A., 2012. Obstructive sleep apnea is associated with fatigue in multiple sclerosis. Mult. Scler. 18, 1159-1169.

KAPPOS L., RADUE E. W., O'CONNOR P., POLMAN C., Hohlfeld R., Calabresi P., Selmaj K., AgOROPOULOU C., LEYK M., ZHANG-AUBERSON L., Burtin P., Freedoms Study Group, 2010. $A$ placebo-controlled trial of oral fingolimod in relapsing multiple sclerosis. N. Engl. J. Med. 362, 387-401.

KIESEIER B. C., 2011. The mechanism of action of interferon- $\beta$ in relapsing multiple sclerosis. CNS Drugs 25, 491-502.

Kohm A. P., CARPentier P. A., Anger H. A., MillER S. D., 2002. Cutting edge: CD4+CD25+ regulatory $T$ cells suppress antigen-specific autoreactive immune responses and central nervous system inflammation during active experimental autoimmune encephalomyelitis. J. Immunol. 169, 4712-4716.

Larochelle C., Alvarez J. I., PRAT A., 2011. How do immune cells overcome the bloodbrain barrier in multiple sclerosis? FEBS Lett. 585, 3770-3780.

LASSMANN H., 2014. Mechanisms of white matter damage in multiple sclerosis. Glia 62, 18161830.

Li R., Rezk A., Miyazaki Y., Hilgenberg E., Touil H., Shen P., MoORe C. S., Michel L., ALTHEKAIR F., RAJASEKHARAN S., GOMMERMAN J. L., Prat A., Fillatreau S., BAR-OR A., 2015. Canadian $B$ cells in MS Team. Proinflammatory GM-CSF-producing $B$ cells in multiple sclerosis and $B$ cell depletion therapy. Sci. Transl. Med.7, doi: 10.1126/scitranslmed.aab4176.

LOVATO L., WILliS S. N., RODIG S. J., CARON T., Almendinger S. E., Howell O. W., ReynoldS R., O'CONNOR K. C., HAFleR D. A., 2011. Related $B$ cell clones populate the meninges and parenchyma of patients with multiple sclerosis. Brain 134, 534-541.

Luger D., Silver P. B., TANG J., CuA D., Chen Z., IWAKURA Y., BOWMAN E. P., SGaMBElloNe N. M., CHAN C. C., CASPI R. R., 2008. Either a Th17 or a Th1 effector response can drive autoimmunity: conditions of disease induction affect dominant effector category. J. Exp. Med. 205, 799-810. 
MAJEWSKA M., ZAJAC K., SREBRO Z., SURA P., KSIAZEK L., ZEMELKA M., SZCZEPANIK M., 2007. Epicutaneous immunization with myelin basic protein protects from the experimental autoimmune encephalomyelitis. Pharmacol. Rep. 59, 74-79.

MAJEWSKA-SZCZEPANIK M., GÓRALSKA M., MARCIŃSKA K., ZEMELKA-WiaceK M., STRZEPA A., DOROŻYŃSKA I., SZCZEPANIK M., 2012a. Epicutaneous immunization with protein antigen TNP-Ig alleviates TNBS-induced colitis in mice. Pharmacol. Rep. 64, 1497-504.

MAJEWSKA-SZCZEPANIK M., STRZEPA A., DROŻYŃSKA I., MOTYL S., BANACH T., SZCZEPANIK M. 2012b. Epicutaneous immunization with hap ten-conjugated protein antigen alleviates contact sensitivity mediated by three different types of effector cells. Pharmacol. Rep. 64, 919-26.

MAJEWSKA-SZCZEPANIK M., ZEMELKA-WIACEK M. PTAK W., WEN L., SZCZEPANIK M., 2012c. Epicutaneous immunization with DNP-BSA induces CD4+ CD25+ Treg cells that inhibit Tc1-mediated CS. Immunol. Cell Biol. 90, 784-795.

MALPASS K., 2012. Multiple sclerosis: 'outside-in' demyelination in MS. Nat. Rev. Neurol. 8, 61.

MANCONI M., ROCCA M. A., FERINI-STRAMBI L., TORTORElla P., AGOStA F., COMI G., FILIPPI M., 2008. Restless legs syndrome is a common finding in multiple sclerosis and cor relates with cervical cord damage. Mult. Scler. 14, 86-93.

MARCiŃSKA K., MAJEWSKA-SZCZEPANIK M., MARESZ K. Z., SzCZEPANIK M. 2015. Epicutaneous immunization with collagen induces TCRa $\beta$ suppressor $T$ cells that inhibit collagen-Induced ar thritis. Int. Arch. Allergy Immunol. 166, 121134

MARcińSKa K., MAJEWSKA-SZCZEPANIK M., LAZAR A. KOWALCZYK P., BIAEA D., WOŹNIAK D., SZCZEPANIK M., 2016. Epicutaneous (EC) immunization with type II collagen (COLL II) induces CD4(+) CD8(+) T suppressor cells that protect from collagen-induced arthritis (CIA). Pharmacol. Rep. 68, 483-489.

Martin R., BieleKova B., Gran B., McFarland H. F., 2000. Lessons from studies of antigen-specific $T$ cell responses in Multiple Sclerosis. J. Neural. Transm. Suppl. 60, 361-373.

MatVeEVA O., BOGIE J. F. J., HENDRIKS J. J. A., Linker R. A., Haghikia A., KLEINEWIETFeld M., 2018. Western lifestyle and immunopathology of multiple sclerosis. Ann. NY Acad. Sci. $1417,71-86$

Mayo L., Cunha A. P., Madi A., Beynon V., Yang Z., Alvarez J. I., Prat A., Sobel R. A., KobZIK L., LASSMANN H., QUINTANA F. J., WEINER H. L., 2016. IL-10-dependent Tr1 cells attenuate astrocyte activation and ameliorate chron ic central nervous system inflammation. Brain 139, 1939-1957.

Melzer N., Meuth S. G., Wiendl H., 2009. CD8+ $T$ cells and neuronal damage: direct and collateral mechanisms of cytotoxicity and impaired electrical excitability. FASEB J. 23, 3659-3673.

Mendozzi L., TRONCI F., Garegnani M., PugnetTI L., 2010. Sleep disturbance and fatigue in mild relapsing remitting multiple sclerosis patients on chronic immunomodulant therapy: an actigraphic study. Mult. Scler. 16, 238-247.

MERLINO G., FRATTICCI L., LENChig C., VAlENTE M., Cargnelutti D., Picello M., Serafini A., Dolso P., Gigli G. L., 2009. Prevalence of 'poor sleep' among patients with multiple scle- rosis: an independent predictor of mental and physical status. Sleep Med. 10, 26-34.

Mikol D. D., BARKhof F., Chang P., COYle P. K., JEFFERY D. R., SCHWID S. R., STUBINSKI B., UitDEHAAG B., REGARD STUDY GROUP, 2008. Comparison of subcutaneous interferon beta-1a with glatiramer acetate in patients with relapsing multiple sclerosis (the REbif vs Glatiramer Acetate in Relapsing MS Disease [REGARD] study): a multicentre, randomised, parallel, open-label trial. Lancet Neurol. 7, 903-914.

MinaGAR A., AleXANDER J. S., 2003. Blood-brain barrier disruption in multiple sclerosis. Mult. Scler. 9, 540-549.

MOLNARFi N., SCHUlze-TOPPHOFF U., WEBER M. S., PATARRoyo J. C., PROD'HOMme T., VARRIN-DOYER M., ShetTy A., Linington C., Slavin A. J., Hidalgo J., Jenne D. E., Wekerle H., Sobel R. A., Bernard C. C., SHLOMCHIK M. J., ZAMVIL S. S., 2013. MHC class II-dependent B cell $A P C$ function is required for induction of CNS autoimmunity independent of myelin-specific antibodies. J. Exp. Med. 210, 2921-2937.

Mondoulet L., Dioszeghy V., Ligouis M., DHelfT V., Dupont C., Benhamou P. H., 2010. Epicutaneous immunotherapy on intact skin using a new delivery system in a murine model of allergy. Clin. Exp. Allergy 40, 659-667.

Munger K. L., Zhang S. M., O'REIlly E., HernáN M. A., OleK M. J., Willett W. C., Ascherio A., 2004. Vitamin D intake and incidence of multiple sclerosis. Neurology 62, 60-65.

Nadjar Y., Coutelas E., PROUTEAU P., PANZER F., Paquet D., SAINT-VAL C., CRÉANGe A., 2011. Injection of interferon-beta in the morning decreases flu-like syndrome in many patients with multiple sclerosis. Clin. Neurol. Neurosurg. 113, 316-322.

PANITCH H. S., HIRSCH R. L., HALEY A. S., JOHNSON K. P., 1987. Exacerbations of multiple sclerosis in patients treated with gamma interferon. Lancet 1, 893-895.

Parkes M., Cortes A., VAN Heel D., Brown M. A., 2013. Genetic insights into common pathways and complex relationships among immune-mediated diseases. Nat. Rev. Genet. 14, 661-673.

Patejdl R., Penner I. K., Noack T. K., ZetTl U. K., 2016. Multiple sclerosis and fatigue: A review on the contribution of inflammation and immune-mediated neurodegeneration. Autoimmun. Rev. 15, 210-220.

POLMAN C. H., O'CONNOR P. W., HAVRdOVA E., Hutchinson M., KAPPOS L., MilleR D. H., Phillips J. T., Lublin F. D., GIOVANNONI G., WAJGT A., TOAL M., LYNN F., PANZARA M. A., SANDROCK A. W., AFFIRM InVESTIGATORS, 2006. A randomized, placebo-controlled trial of natalizumab for relapsing multiple sclerosis. $\mathrm{N}$. Engl. J. Med. 354, 899-910.

PTAK W., SZCZEPANIK M., BRYNIARSKI K., TUTAJ M., PTAK M., 2002. Epicutaneous application of protein antigens incorporated into cosmetic cream induces antigen-nonspecific unresponsiveness in mice and affects the cell-mediated immune response. Int. Arch. Allergy Immunol. $128,8-14$.

RANSOHOFF R. M., 2007. Natalizumab for multiple sclerosis. N. Engl. J. Med. 356, 2622-2629.

RANSOHOFF R. M., 2016. How neuroinflammation contributes to neurodegeneration. Science 353, 777-783.

Ristori G., Cannoni S., Stazi M. A., Vanacore N., COTIChini R., AlFò M., PugliatTi M., SOTGIU S., SOlaro C., BOMPREZZI R., Di GIOVANNI S., TAlamanca L. F., Nisticò L., FAgnani C., 
Neale M. C., Cascino I., Giorgi G., Battaglia M. A., ButTinelli C., Tosi R., SAlvetti M., 2006. Multiple sclerosis in twins from continental Italy and Sardinia: a nationwide study. Ann. Neurol. 59, 27-34.

Schneider A., Long S. A., Cerosaletti K., Ni C. T., SAMUels P., KITA M., BuCKNeR J. H., 2013. In active relapsing-remitting multiple sclerosis, effector $T$ cell resistance to adaptive T(regs) involves IL-6-mediated signaling. Sci. Transl. Med. 5, doi: 10.1126/scitranslmed.3004970.

SchutTe-RodiN S., BROCH L., BuYsSE D., DORSEY C., SATEIA M., 2008. Clinical guideline for the evaluation and management of chronic insomnia in adults. J. Clin. Sleep Med. 4, 487-504.

Schwarz A., Schumacher M., PfafF D., SchumACHER K., JARIUS S., BALINT B., WIENDL H., HAAS J., WILDEMANN B., 2013. Fine-tuning of regulatory $T$ cell function: the role of calcium signals and naive regulatory $T$ cells for regulatory $T$ cell deficiency in multiple sclerosis. J. Immunol. 190, 4965-4970.

Segal B. M., Constantinescu C. S., RaychaudhuRI A., KIM L., FIDELUS-GORT R., KASPER L. H., USTEKINUMAB MS INVESTIGATORS, 2008. Repeated subcutaneous injections of IL12/23 p40 neutralising antibody, ustekinumab, in patients with relapsing-remitting multiple sclerosis: a phase II, double-blind, placebo-controlled, randomised, dose-ranging study. Lancet Neurol. 7, 796-804.

SellebJerg F., Cadavid D., Steiner D., Villar L. M., ReYNOLDS R., MikOL D., 2016. Exploring potential mechanisms of action of natalizum$a b$ in secondary progressive multiple sclerosis. Ther. Adv. Neurol. Disord. 9, 31-43.

Sintzel M. B., RAmetTA M., Reder A. T., 2018. Vitamin $D$ and Multiple Sclerosis: A Comprehensive Review. Neurol. Ther. 7, 59-85.

StANTON B. R., BARNeS F., Silber E., 2006. Sleep and fatigue in multiple sclerosis. Mult. Scler. $12,481-486$

STRZEPA A., LOBO FM., MAJEWSKA-SZCZEPANIK M., SZCZEPANIK M., 2018; Antibiotics and autoimmune and allergy diseases: Causative factor or treatment? Int Immunopharmacol. 65, 328341.

STUDY GROUP, 1993. Neurology Interferon beta-1b is effective in relapsing-remitting multiple sclerosis. I. Clinical results of a multicenter, randomized, double-blind, placebo-controlled trial. The IFNB Multiple Sclerosis 43, 655-661.

SWAMY M., JAMORA C., HAVRAN W., HAYDAY A., 2010. Epithelial decision makers: in search of the 'epimmunome'. Nat. Immunol. 11, 656665.

Sweeney M. D., Sagare A. P., Zlokovic B. V., 2018. Blood-brain barrier breakdown in Alzheimer disease and other neurodegenerative disorders. Nat. Rev. Neurol. 14, 133-150.

SZCZEPANIK M., MAJEWSKA-SZCZEPANIK M., 2016. Transdermal immunotherapy: past, present and future. Pharmacol. Rep. 68, 773-781.

SZCZEPANIK M., BRYNIARSKI K., TUTAJ M., PTAK M., SKRZECZYNSKA J., ASKENASE P. W., PTAK W., 2005. Epicutaneous immunization induces al- phabeta T-cell receptor CD4 CD8 double-positive non-specific suppressor $T$ cells that inhibit contact sensitivity via transforming growth factor-beta. Immunology 115, 42-54.

TACHIBANa N., HOWARD R. S., HIRSCH N. P., MillER D. H., MOseley I. F., Fish D., 1994. Sleep problems in multiple sclerosis. Eur. Neurol. 34, 320-323

TAN G., XU P., Lawson L. B., HE J., Freytag L. C., Clements J. D., John V. T., 2010. Hydration effects on skin microstructure as probed by high-resolution cryo-scanning electron microscopy and mechanistic implications to enhanced transcutaneous delivery of biomacromolecules. J. Pharm. Sci. 99, 730-740.

THOMPSON A. J., BARANZINI S. E., GEURTS J., HeMmer B., CiCCAREll O., 2018. Multiple sclerosis. Lancet 391, 1622-1636.

TRAugotT U., REINHERZ E. L., RAINE C. S., 1983. Multiple sclerosis. Distribution of $T$ cells, $T$ cell subsets and Ia-positive macrophages in lesions of different ages. J. Neuroimmunol. 4, 201-221.

TUTAJ M., SzCZEPANIK M., 2006. Mechanizmy regulacji odpowiedzi immunologicznej $w$ modelu stwardnienia rozsianego u myszy. Post. Hig. Med. Dosw. 60, 571-583.

TUTAJ M., SZCZEPANIK M., 2007. Epicutaneous (EC) immunization with myelin basic protein (MBP) induces TCRalphabeta+ CD4+ CD8+ double positive suppressor cells that protect from experimental autoimmune encephalomyelitis (EAE). J. Autoimmun. 28, 208-215.

VAUGHAN K., PETERS B., O'CONNOR K. C., MARTIN R., SeTte A., 2014. A molecular view of multiple sclerosis and experimental autoimmune encephalitis: what can we learn from the epitope data? J. Neuroimmunol. 267, 73-85.

WALCZAK A., SigER M., CIACH A., SZCZEPANIK M., SELMAJ K., 2013. Transdermal application of myelin peptides in multiple sclerosis treatment. JAMA Neurol. 70, 1105-1109.

WierinckX A., BREvé J., MERCIER D., SchulTZBERG M., DRUKARCH B., VAN DAM A. M., 2005. Detoxication enzyme inducers modify cytokine production in rat mixed glial cells. J. Neuroimmunol. 166, 132-143.

Willer C. J., Dyment D. A., Risch N. J., SADOVNick A. D., Ebers G. C., Canadian CollaboRATIVE STUDY GROUP, 2003. Twin concordance and sibling recurrence rates in multiple sclerosis. Proc. Natl. Acad. Sci. USA 100, 1287712882.

ZANG Y. C., Li S., Rivera V. M., HONG J., ROBINSON R. R., BREITBACH W. T., KILLIAN J., ZHANG J. Z., 2004. Increased CD8+ cytotoxic $T$ cell responses to myelin basic protein in multiple sclerosis. J. Immunol. 172, 5120-5127.

ZEMELKA-WIACEK M., MAJEWSKA-SZCZEPANIK M., PTAK W., SZCZEPANIK M., 2012. Epicutaneous immunization with protein antigen induces antigen-non-specific suppression of CD8 T cell mediated contact sensitivity. Pharmacol. Rep. 64, 1485-1496. 
KOSMOS Vol. 69, 3, 523-536, 2020

Anna Strzępa, Barbara Macura, Marian Szczepanik

Chair of Medical Biology, Faculty of Health Sciences, Jagiellonian University Medical College, 7 Kopernika Str., 31 -034 Kraków, E-mail: mmszczep@cyf-kr.edu.pl, marian.szczepanik@uj.edu.pl

\section{SLEEP DISORDERS IN MULTIPLE SCLEROSIS}

\section{Summary}

Multiple sclerosis (Lat. sclerosis multiplex, SM) is an autoimmune disease in which lymphocytes, autoreactive to nerve cell antigens, infiltrate the central nervous system and bring about its damage. This condition leads to a continuous or relapsing progressive deterioration in physical, cognitive, emotional, and social functions of a patient. In 43 to $67 \%$ of MS patients, sleep-related abnormalities such as insomnia, circadian rhythm disturbances, movement disorders, and breathing disorders are observed. These disorders can worsen the course of MS, and MS can worsen and increase the likelihood of sleep disorders. This two-way relationship arises due to the role of the immune system in the pathogenesis of MS and sleep disorders. In this review article, we present the latest information on the etiology and role of the immune system in MS and the immunopathomechanism of this disease, paying particular attention to coexisting sleep disorders. We also discuss sleep disorders that coexist with MS. Further, we discuss MS therapies with particular emphasis on the epicutaneous application of the protein antigen, which, in addition to reducing the progression of the disease, may potentially reduce the severity of sleep disorders.

Key words: immunopathology, multiple sclerosis, sleep abnormalities, therapy 